\title{
Data report: late Quaternary ostracodes at IODP Site U1314 (North Atlantic Ocean)'
}

\author{
Carlos A. Alvarez Zarikian²
}

\section{Chapter contents}

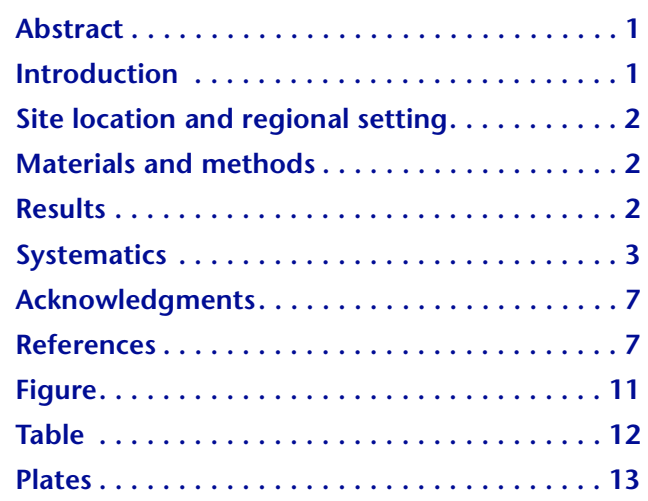

${ }^{1}$ Alvarez Zarikian, C.A., 2009. Data report: late Quaternary ostracodes at IODP Site U1314 (North Atlantic Ocean). In Channell, J.E.T., Kanamatsu, T., Sato, T., Stein, R., Alvarez Zarikian, C.A., Malone, M.J., and the Expedition 303/306 Scientists, Proc. IODP, 303/306: College Station, TX (Integrated Ocean Drilling Program Management International, Inc.). doi:10.2204/iodp.proc.303306.213.2009 ${ }^{2}$ Integrated Ocean Drilling Program and Department of Oceanography, Texas A\&M University, 1000 Discovery Drive, College Station TX 77845, USA. zarikian@iodp.tamu.edu

\begin{abstract}
This report presents the taxonomy of late Quaternary deep-sea benthic ostracodes found at Integrated Ocean Drilling Program Site U1314 in the subpolar North Atlantic. It provides high-quality scanning electron microscope images of most of the observed species and links to key references for their identification, geographical distribution, ecology, and interpretation.
\end{abstract}

\section{Introduction}

Ostracodes, calcareous bivalve microcrustaceans, are the only metazoan organisms commonly preserved as microfossils in deepsea sediments in sufficient quantities for detailed paleoceanographic studies. Detailed investigations of modern and recent regional distribution of ostracode species from shelf, slope, bathyal, and abyssal environments indicate that their distribution is strongly influenced by the physico-chemical characteristics of water masses (e.g., temperature, salinity, nutrients, dissolved oxygen, etc.), as well as substrate type and food supply (Benson et al., 1983; Dingle et al., 1989; Dingle and Lord, 1990; Corrège, 1993; Cronin et al., 1994, 1995, 2002; Whatley et al., 1998; Ayress et al., 1997, 2004).

Recent paleoceanographic reconstructions of Arctic and North Atlantic environments during the last glacial-interglacial climatic cycle using ostracode assemblages imply that their taxonomic composition can be a good environmental indicator and provides an effective tool for a broad range of paleoceanographic and paleoenvironmental analyses (e.g., Jones et al., 1998; Cronin et al., 1999; Didié and Bauch, 2000; Yasuhara et al., 2008a). By analyzing and comparing ostracode assemblage changes to modern and recent analogies from different water masses, these researchers were able to reconstruct changes in ocean circulation, bottom temperature, salinity, and oxygen content during the late Quaternary.

In this report I focus on the taxonomic composition of the late Quaternary deep-sea benthic ostracode assemblages found at Integrated Ocean Drilling Program (IODP) Site U1314 in the subpolar North Atlantic and illustrate most of identified species with highquality scanning electron microscope (SEM) images. This report complements a recently published manuscript by Alvarez Zarikian et al. (2009), which examines the significance of glacial and 
interglacial variability in the ostracode assemblage composition and provides a paleoceanographic interpretation based on known ecological preferences of the taxa.

\section{Site location and regional setting}

Site U1314 was cored at $2820 \mathrm{~m}$ water depth using the R/V JOIDES Resolution during IODP Expedition 306. The site is located on the southeastern flank of the Reykjanes Ridge in an area known as the southern Gardar Drift in the subpolar North Atlantic $\left(56.36^{\circ} \mathrm{N}, 27.88^{\circ} \mathrm{W}\right)$ (Fig. F1). Its deposition is believed to be linked to changing deep-ocean circulation patterns in the North Atlantic (Dickson and Brown, 1994) and its shape and location controlled by pre-existing topography and sediment supply (McCave and Tucholke, 1986).

Site U1314 is situated close to the ice-rafted debris (IRD) belt for high-resolution monitoring of North Atlantic Deep Water (NADW) variability and ice sheet instability (see the "Expedition 306 summary" chapter; Stein et al., 2006). The site is complementary to Ocean Drilling Program (ODP) Sites 983 $\left(60^{\circ} 24.2^{\prime} \mathrm{N}, 23^{\circ} 38.4^{\prime} \mathrm{W}, 1985 \mathrm{~m}\right.$ water depth) and 984 $\left(61^{\circ} 25.5^{\prime} \mathrm{N}, 24^{\circ} 04.9^{\prime} \mathrm{W}, 1648 \mathrm{~m}\right.$ water depth) drilled south of Iceland on the northern part of the Gardar and Bjorn drifts during ODP Leg 162 (Jansen, Raymo, Blum, et al., 1996), which were selected for monitoring intermediate water circulation (Channel et al., 1997; see the "Expedition 306 summary" chapter). Sites 983 and 984 have produced high-resolution climatic and geomagnetic records (e.g., Raymo et al., 1998; Channell et al., 1998; Flower et al., 2000).

Three holes were drilled and cored at Site U1314 using the JOIDES Resolution's advanced hydraulic piston corer system (see the "Site U1314" chapter). The maximum depth reached was 279.91 meters below seafloor in Hole U1314B. The holes were correlated aboard ship using sediment core physical properties. The obtained correlations were used to construct a composite section (or splice) for the site, providing an optimal record of the sedimentary sequence. The spliced section was completed to 281 meters composite depth (mcd). Shipboard magnetic and biostratigraphic analyses suggest that the oldest sediments recovered were deposited close to 3 m.y. ago (see the "Site U1314" chapter).

Late Pleistocene and Holocene sediments at Site U1314 consist predominantly of pelagic sediments containing well-preserved biogenic components including calcareous (e.g., nannofossils and planktonic foraminifers) and siliceous (e.g., diatoms and radiolarians) microfossils and a lower content of terrigenous components such as clay, quartz, and dark minerals. Changes in the relative proportions of these two sediment types likely reflect variable depositional rates, sea-surface productivity, and sediment provenance (see the "Site U1314" chapter).

\section{Materials and methods}

\section{Micropaleontological analyses}

I analyzed the upper $\sim 14 \mathrm{~m}$ sedimentary section for ostracode fauna characterization and IRD content. Samples ( $2 \mathrm{~cm}$ thick slices) were taken at $10 \mathrm{~cm}$ intervals using two $10 \mathrm{~cm}^{3}$ plastic scoops. Sampling resolution was increased to $5 \mathrm{~cm}$ at selected intervals where more detailed examination was desired. The obtained $20 \mathrm{~cm}^{3}$ samples were washed with deionized water over a $63 \mu \mathrm{m}$ sieve and dried and later dry sieved into subfractions of 125-250 $\mu \mathrm{m}$ and $>250$ $\mu \mathrm{m}$. All ostracodes from the $>125 \mu \mathrm{m}$ size fraction were picked, identified, and counted. This method assured that all adults and, for most species, two to three prior molt stages were attained. Ostracodes were characterized exclusively by the morphology of the valves following descriptions and SEM images provided by Joy and Clark (1977), Whatley and Coles (1987), Whatley et al. (1996, 1998), RodriguezLazaro and Cronin (1999), Swanson and Ayress (1999), Didié and Bauch (2001), and Stepanova (2006). Most specimens were identified to species level, but some were only identified to genus level. Ostracode assemblages were characterized by calculating the total ostracode abundance, species diversity (number of species and Shannon Weaver index), and relative abundance of individual taxa (percent). These results and their interpretation are presented in Alvarez Zarikian et al. (2009).

Ostracodes were imaged using JEOL JSM-6400 and FEI Quanta 600 FE scanning electron microscopes at the Texas A\&M University Microscopy and Imaging Center.

\section{Results}

Site U1314 yielded a numerous and taxonomically diverse mixture of ostracode species that included the typical deep-sea North Atlantic taxa, as well as subarctic and some Arctic upper slope and shelf species. We recognized more than 75 species belonging to 40 genera (Table T1). Krithe, Cytheropteron, and Argilloecia are the most taxonomically diverse genera. These are also the most diverse and copious deep-sea genera in upper Pleistocene sediments on 
the Rockall Plateau (Didié and Bauch, 2000) and at other North Atlantic sites (Dingle and Lord, 1990; Van Harten, 1990; Coles et al., 1994; Cronin et al., 1999). The most abundant genera are Krithe (38\%$87 \%)$, Rockallia (0\%-33\%), Pennyella (0\%-30\%), Pelecocythere (0\%-32\%), Cytheropteron (0\%-20\%), Henryhowella (0\%-24\%), Argilloecia (0\%-23\%), Legitimocythere (0\%-15\%), Pseudobosquetina (0\%-14.5\%), Ambocythere (0\%-13\%), Echinocythereis (0\%-9\%), and Bradleya (0\%-12\%). Other genera, such as Bythocythere $(0 \%-17 \%)$, Bathycythere (0\%-9\%), Eucythere (0\%-7\%), Polycope (0\%-9\%), Propontocypris (0\%-6\%), Xestoleberis (0\%-15\%), Pontocypris (0\%-11\%) and Paracytherois (0\%-9\%) only arise during discrete intervals in our sedimentary record. All these genera have worldwide distribution and are common in deep-sea Cenozoic sediments (Dingle and Lord, 1990). Arctic shelf species occur in very low numbers in samples with high IRD and include Cluthia cluthae, Elofsonella concinna, Finmarchinella finmarchica, and Heterocyprideis sorbyana (Alvarez Zarikian et al., 2009).

\section{Systematics}

A list of all Late Quaternary ostracodes found at Site U1314 with key references used for their identification is presented below following the suprageneric taxonomy provided by Whatley and Coles (1987) and updated using the Integrated Taxonomic Information System (www.itis.gov). High-quality SEM photomicrographs are provided for most species. Notes on geographical distribution, ecology, and interpretation can be found in Alvarez Zarikian et al. (2009).

\section{Phylum ARTHROPODA Siebold and Stannius, 1845 \\ Subphylum CRUSTACEA Pennant, 1777 Class OSTRACODA Latreille, 1802 Subclass MYODOCOPA Sars, 1866 Order HALOCYPRIDA Dana, 1853 Suborder CLADOCOPINA Sars, 1866 Family POLYCOPIDAE Sars, 1866 Genus Polycope Sars, 1866}

Polycope cf. P. clathrata Joy and Clark (1977), Pl. P1, fig. 6 (Whatley et al., 1998).

Polycope orbicularis Sars, 1866, Pl. P1, fig. 7 (Whatley et al., 1998; Stepanova, 2006).

Polycope punctata Sars, 1870 (Joy and Clark, 1977).

Remarks: Polycope is found during glacial and stadial intervals. The downcore distribution trends are similar to those found in other late Quaternary sequences in the subpolar North Atlantic (Didié and Bauch, 2000, 2002; Didié et al., 2002) where the genus is considerably more abundant (Alvarez Zarikian et al., 2009).
Order PODOCOPIDA Müller, 1894

Suborder CYTHEROCOPINA Sars, 1866

Superfamily CYTHEROIDEA Baird, 1850

Family BYTHOCYTHERIDAE Sars, 1866

Genus Bythocythere Sars, 1866

Bythocythere bathytatos Whatley and Coles, 1987, P1. P2, fig. 3 (Whatley and Coles, 1987).

Remarks: $B$. bathytatos is most abundant during marine isotope stages (MIS) 6, 5d, and 2. This species was first recovered from upper Quaternary sediments at $>3400 \mathrm{~m}$ water depth in the central North Atlantic (Whatley and Coles, 1987; Cronin et al., 1999). It was recently reported from very cold waters $\left(1.2^{\circ} \mathrm{C}\right) 5032 \mathrm{~m}$ east of the Walvis Ridge in the eastern South Atlantic (Yasuhara et al., 2008b). B. bathytatos also shows a glacial/stadial distribution in the upper Pleistocene sediments at the Rockall Plateau in the eastern North Atlantic (Didié and Bauch, 2000).

\section{Genus Pseudocythere Sars, 1866}

Pseudocythere caudata Sars, 1866, P1. P2, fig. 4 (Whatley et al., 1998; Stepanova, 2006).

Pseudocythere sp. 2 sensu Didié and Bauch (2000), P1. P2, fig. 6 .

Remarks: Species of Pseudocythere were found in samples corresponding to glacial intervals. $P$. caudata has been found worldwide in the deep ocean and it is common in the Arctic Ocean (Joy and Clark, 1977; Didié and Bauch, 2000). Pseudocythere sp. 2 has also been found in glacial sediments from the Rockall Plateau (Didié and Bauch, 2000).

\section{Family CYTHERIDAE Baird, 1850}

Genus Nannocythere Schäfer, 1953

Nannocythere sp., Pl. P2, fig. 1 (Whatley et al., 1998; Didié and Bauch, 2000, 2001).

Remarks: Nannocythere sp. is found in very low numbers during interglacials.

Family CYTHERIDEIDAE Sars, 1925

Genus Heterocyprideis Elofson, 1941

Heterocyprideis sorbyana (Jones) 1857 (Cronin, 1981; Stepanova, 2006).

Remarks: A single valve of $H$. sorbyana was found in sediments corresponding to the last glacial interval (MIS 2 ). This species lives in cold regions of the Atlantic and in the Arctic Ocean (Cronin, 1981).

Family CYTHERURIDAE Müller, 1894

Genus Aversovalva Hornibrook, 1952

Aversovalva hydrodynamica Whatley and Coles, 1987, Pl. P3, fig. 7 (Whatley and Coles, 1987).

Remarks: One complete carapace was found in a sample corresponding to the Holocene. The species was also found in interglacial sediments at the Rockall Plateau (Didié and Bauch, 2000). 


\section{Genus Cytheropteron Sars, 1866}

Cytheropteron alatum Sars, 1866, Pl. P3, fig. 4 (Joy and Clark, 1977; Didié and Bauch, 2000, 2001).

Cytheropteron arcuatum Brady, Crosskey, and Robertson, 1874, Pl. P4, fig. 8 (Whatley and Masson, 1979; Stepanova et al., 2004).

Cytheropteron carolinae Whatley and Coles, 1987, P1. P4, fig. 7 (Whatley and Coles, 1987).

Cytheropteron champlainum Cronin, 1981 (Cronin, 1981).

Cytheropteron circummuralla Whatley and Coles, 1987, Pl. P4, figs. 3, 4 (Whatley and Coles, 1987).

Cytheropteron hamatum Sars, 1869 (Whatley et al., 1998).

Cytheropteron lineoporosa Whatley and Coles, 1987, P1. P3, figs. 3, 5 (Whatley and Coles, 1987).

Cytheropteron massoni Whatley and Coles, 1987 (Whatley and Coles, 1987).

Cytheropteron perlaria Hao, 1988, Pl. P3, figs. 1, 2 (Hao, 1988; Stepanova, 2006; as C. testudo in Whatley and Coles, 1987).

Cytheropteron pherozigzag Whatley and Ayress, 1988 (Whatley and Coles, 1987).

Cytheropteron porterae Whatley and Coles, 1987, Pl. P4, figs. 5, 6 (Whatley and Coles, 1987).

Cytheropteron syntomalatum Whatley and Coles, 1987, Pl. P3, fig. 6 (Whatley and Coles, 1987).

Cytheropteron tenuialatum Whatley and Coles, 1987, Pl. P4, figs. 1, 2 (Whatley and Coles, 1987).

Cytheropteron tressleri Whatley and Coles, 1987 (Whatley and Coles, 1987).

Cytheropteron trifossata Whatley and Coles, 1987 (Whatley and Coles, 1987).

Remarks: More than 14 species of Cytheropteron were found in late Quaternary sediments at Site U1314, making it the most diverse genus at the site. Most common species are C. syntomalatum, C. porterae, C. perlaria, C. tenuialatum, and $C$. circummuralla. Although found throughout the entire stratigraphic section, Cytheropteron species are most abundant during MIS 6, 4, and 2, particularly during deglaciations (Alvarez Zarikian et al., 2009). Lowest abundances $(<5 \%)$ are observed during the Eemian, the Holocene, and early in MIS 3. C. arcuatum, C. champlainum, C. lineoporosa, and $C$. trifossata are found as single specimens in samples with high IRD content and associated with deglaciations. C. arcuatum and C. champlainum are commonly found at shallower depths on the shelf/upper slope in the North Atlantic and Arctic seas (Stepanova et al., 2004, and references therein).

\section{Genus Eucytherura Müller, 1894}

Eucytherura calabra (Cotalongo and Pasini) 1980 (Whatley and Coles, 1987).

Remarks: Widespread in deep-sea sediments worldwide, it was found as single specimens in only four samples.

\section{Genus Pedicythere Eagar, 1965}

Pedicythere polita Colalongo and Pasini, 1980 (Whatley and Coles, 1987).
Remarks: Members of this genus were previously reported from deep-sea sediments in the deep North Atlantic (Cronin, 1983; Whatley and Coles, 1987), Greenland Sea (Whatley et al., 1998), and Arctic Ocean (Joy and Clark, 1977; Jones et al., 1998). Pedicythere polita was found in low numbers in samples corresponding to glacial and stadial intervals.

\section{Genus Pelecocythere Athersuch, 1979}

Pelecocythere sylvesterbradleyi Athersuch, 1979, Pl. P5, fig. 4 (Athersuch, 1979; Whatley and Coles, 1987).

Remarks: Pelecocythere sylvesterbradleyi is a common deep-water species in the North Atlantic (Neale, 1988). It exhibited maximum abundances during MIS 5e at Site U1314 and was reported as the major component of the "interglacial" assemblage in upper Quaternary sediments in the Iceland Plateau (Didié et al., 2002). Similarly, it has also been reported as a typical component of interglacial assemblages at other North Atlantic sites (e.g., Cronin et al., 1996, 1999; Didié and Bauch, 2000).

\section{Genus Rimacytheropteron Whatley and Coles, 1987}

Rimacytheropteron longipunctata (Breman) 1976. Pl. P3, fig. 8 (Whatley and Coles, 1987).

Remarks: A single specimen of $R$. longipunctata was found in a core sample corresponding to $\sim 145 \mathrm{ka}$.

\section{Genus Semicytherura Wagner, 1957}

Remarks: A single valve of an unidentified species of Semicytherura was found in a core sample corresponding to $\sim 70 \mathrm{ka}$.

\section{Genus Swainocythere Ishizaki, 1981}

Swainocythere nanseni (Joy and Clark) 1981, P1. P2, fig. 7 (as Cytheroteron? nealei in Joy and Clark, 1977; Corrège et al., 1992; Didié and Bauch, 2000, 2001).

Swainocythere sp.1 sensu Didié and Bauch $(2000,2001) \mathrm{Pl}$. P2, fig. 8.

Remarks: Species of Swainocythere were found in low numbers in $\sim 10$ samples. S. nanseni is found today in the deep Arctic Ocean (Joy and Clark, 1977; Jones et al., 1998) and around Australia (Corrège et al., 1992).

\section{Family EUCYTHERIDAE Puri, 1954 Genus Eucythere Brady, 1868}

Eucythere argus (Sars) 1866 (Cronin, 1981; Whatley et al., 1998).

Eucythere circumcostata Whatley and Coles, 1987, Pl. P6, fig. 2 (Whatley and Coles, 1987).

Eucythere multipunctata Whatley and Coles, 1987, P1. P6, fig. 1 (Whatley and Coles, 1987).

Eucythere pubera Bonaduce, Ciampo, and Masoli, 1975, Pl. P6, fig. 3 (Whatley and Coles, 1987).

Eucythere triangula Whatley and Coles, 1987, Pl. P6, fig. 4 (Whatley and Coles, 1987). 
Eucythere sp. B sensu Whatley et al. (1998), Pl. P6, fig. 5.

Remarks: Species of Eucythere occur in only a few samples associated with elevated IRD content, where they reached up to $7 \%$ of the assemblage. These intervals correspond to MIS 5d, 5b, 4, and 2 (Alvarez Zarikian et al., 2009). Species of Eucythere have been recovered from water depths from 650 to $>4000 \mathrm{~m}$ from the Greenland Sea (Whatley et al., 1998) to the middle North Atlantic (Whatley and Coles, 1987) and many of them are restricted at depths $>3000 \mathrm{~m}$ (Dingle and Lord, 1990). Eucythere has been recorded at glacial-interglacial transitions in upper Quaternary sediment sequences from the polar and subpolar North Atlantic (Didié and Bauch, 2000; Didié et al., 2002).

Family HEMICYTHERIDAE Puri, 1953

Genus Finmarchinella Swain, 1963

Finmarchinella finmarchica (Sars) 1865, Pl. P6, figs. 6, 7 (Cronin, 1991).

Remarks: This species was found as single valves in samples with high IRD content. Members of this genus are very abundant in the Northern Seas (Neale and Howe, 1975; Cronin, 1991; Didié and Bauch, 2000).

\section{Genus Hemicythere Sars, 1925}

Hemicythere villosa (Sars) 1866, Pl. P6, fig. 8 (Athersuch et al., 1989; Didié and Bauch, 2001).

Remarks: A single valve of $H$. villosa was found in a sample corresponding to $\sim 41 \mathrm{ka}$. Amphiatlantic species are found along the Arctic coasts (Cronin et al., 1993).

Family KRITHIDAE Mandelstam, 1958 Genus Krithe Brady, Crosskey, and Robertson, 1874

Krithe cf. K. aequabilis Campo, 1986, Pl. P7, fig. 2 (Coles et al., 1994; Rodriguez-Lázaro et al., 1999).

Krithe cf. K. dolichodeira van den Bold, 1946, Pl. P7, fig. 3, 4 (Coles et al., 1994) .

Krithe cf. K. minima Coles, Whatley, and Moguilevsky, 1994 (Coles et al., 1994; Rodriguez-Lázaro et al., 1999).

Krithe morkhoveni van den Bold, 1960, Pl. P7, fig. 1 (Coles et al., 1994; Rodriguez-Lázaro et al., 1999).

Krithe trinidadensis van den Bold, 1958, Pl. P7, fig. 5 (Coles et al., 1994; Rodriguez-Lázaro et al., 1999).

Remarks: The genus Krithe in our samples was represented by at least 3-4 species. It was most dominant during the 150-165 ka interval in MIS 6, the early half of MIS 5e, immediately after peak stadial (MIS $5 \mathrm{~d}$ and $5 \mathrm{~b}$ ), during most of MIS 3, and the early part of the Holocene (Alvarez Zarikian et al., 2009).

\section{Family LOXOCONCHIDAE Sars, 1925 Genus Heinia van den Bold, 1985}

Heinia dryppa Whatley and Coles, 1987, P1. P2, fig. 2 (Whatley and Coles, 1987).

Remarks: Few specimens, including one complete carapace, were found in a core sample dated at $120 \mathrm{ka}$. This species also occurs in the southwest Pacific and Indian Ocean (Whatley and Coles, 1987).

\section{Genus Loxoconcha Sars, 1866}

?Loxoconcha sp., Pl. P7, figs. 7, 8 .

Remarks: An unidentified species resembling a Loxoconchiid occurs in several core samples corresponding to the Holocene and the last interglacial.

\section{Family MICROCYTHERIDAE Klie, 1938 Genus Microcythere Müller, 1894}

Microcythere medistriata (Joy and Clark, 1977), Pl. P8, figs. 7, 8 (Joy and Clark, 1977).

Remarks: A single carapace of $M$. medistriata was found in a sample corresponding to $\sim 8 \mathrm{ka}$.

\section{Family PARADOXOSTOMATIDAE Brady and Norman, 1889 \\ Genus Cytherois Müller, 1884}

Cytherois pusilla Sars 1928.

Remarks: Three valves of this species were found in the core section in intervals corresponding to deglaciations.

\section{Genus Paracytherois Müller, 1894}

Paracytherois flexuosa (Brady) 1867, Pl. P8, fig. 9 (Whatley et al., 1998).

Remarks: Few specimens of this species were found in the core section. $P$. flexuosa has been previously reported from the Greenland Sea shelf (Whatley et al., 1998).

Family ROCKALLIIDAE Whatley et al., 1982 Genus Rockallia Whatley, Frame, and Whittaker, 1978

Rockallia enigmatica Whatley, Frame, and Whittaker, 1978, Pl. P9, fig. 5 (Whatley and Coles, 1987; Whatley et al., 1982; Ayress, 1991).

Remarks: $R$. enigmatica is one of the most abundant species at Site U1314, reaching $>20 \%$ of the total assemblage during MIS 3 and glacial and deglacial transitions. In contrast, it was nearly absent during full interglacial and glacial intervals (Alvarez Zarikian et al., 2009). R. enigmatica shows a similar stratigraphic distribution on the southern Rockall Plateau but it was generally less abundant there (Didié and Bauch, 2000). It is considered a bathyal and abyssal species found in the North Atlantic (Whatley et al., 1982). The genus Rockallia is a junior synonym of the genus Arcacythere Hornibrook, 1952 (Ayress, 1991), but I kept Rockallia in this report for consistency with the North Atlantic literature.

Family TRACHYLEBERIDIDAE Sylvester-Bradley, 1948 Genus Ambocythere van den Bold, 1957

Ambocythere ramosa van den Bold, 1965, Pl. P10, fig. 7 (Whatley and Coles, 1987).

Remarks: A. ramosa reached highest proportions during MIS 5e and 5c and the Holocene (Alvarez Zarikian et al., 
2009). It was common in deep-sea Core M23414 from the southern Rockall Plateau, where it reached its greatest relative abundance (3.5\%) during MIS 5 (Didié and Bauch, 2000). A. ramosa was also reported from the North Atlantic deep waters (Whatley and Coles, 1987).

\section{Genus Bathycythere Sissingh 1971}

Bathycythere audax (Brady and Norman, 1869; as B. vanstraateni Sissingh 1971 in Dingle and Lord, 1990), Pl. P5, fig. 5 (Whatley and Coles, 1987).

Remarks: $B$. audax peaked in core samples corresponding to MIS 6, 4, and 2 (Alvarez Zarikian et al., 2009). This species is restricted to water depths $>3000 \mathrm{~m}$ in the Atlantic and temperatures $<3^{\circ} \mathrm{C}$. Its upper depth distribution limits are restricted to the lowermost part of the NADW (Dingle and Lord, 1990). In the southwest Pacific and South Indian oceans, $B$. audax has been found between 1900 and $3584 \mathrm{~m}$ in coldwater masses associated with the Deep Water and Antarctic Bottom Water (AABW) (Ayress et al., 2004).

\section{Genus Bradleya Hornibrook, 1952}

Bradleya dictyon (Brady) 1880, Pl. P5, figs. 8, 9; Pl. P9, fig. 1 (Whatley and Coles, 1987).

Bradleya normani Brady, 1865, Pl. P9, fig. 2 (Benson, 1972).

Remarks: Two species of Bradleya were recognized. The genus displays an interglacial and interstadial distribution pattern, reaching maximum relative abundances ( 15\%) during MIS 5e (Alvarez Zarikian et al., 2009). The species are known from the deep waters of the Atlantic Ocean (Guernet and Fourcade, 1988).

\section{Genus Dutoitella Dingle, 1981}

Dutoitella suhmi (Brady, 1880), Pl. P5, figs. 6, 7 (Whatley and Coles, 1987).

Remarks: Abyssal species D. suhmi peaked in discrete samples during MIS 6, 4, and 2 (Alvarez Zarikian et al., 2009). In the Atlantic, this species is restricted to water depths $>3000 \mathrm{~m}$ and temperatures $<3^{\circ} \mathrm{C}$. Its upper depth limits are restricted to the lowermost part of the NADW (Dingle and Lord, 1990). In the southwest Pacific and South Indian oceans, D. suhmi has been reported from a water depth $>3584 \mathrm{~m}$ and temperatures $<1^{\circ} \mathrm{C}$ (Ayress et al., 2004).

\section{Genus Echinocythereis Puri, 1954}

Echinocythereis echinata (Sars) 1866, Pl. P9, figs. 3, 4 (Whatley and Coles, 1987).

Remarks: E. echinata reached highest relative abundances (>7\%) during an interval in MIS 6, as well as during MIS 4. However, it was also present, though slightly less abundant, during MIS 5e, 5c, and 3 (Alvarez Zarikian et al., 2009). E. echinata appears to be restricted to the region between mid and low latitudes in the Atlantic at water depths ranging from 500 to $3884 \mathrm{~m}$ (Dingle and Lord, 1990; Didié et al., 2002). This species has been associated with interglacial assemblages in the central (Cronin et al.,
1999) and northeastern North Atlantic (Didié and Bauch, 2000).

\section{Genus Henryhowella Puri, 1957}

Henryhowella asperrima (Reuss) 1850 (Whatley and Coles, 1987).

Henryhowella dasyderma (Brady) 1880, Pl. P9, figs. 6, 7, 8 (Whatley and Coles, 1987).

Remarks: Genus Henryhowella (mainly $H$. cf. dasyderma with occasionally occurring $H$. cf. asperrima) was consistently present throughout the cored section (average $\sim 5 \%$ ) reaching maximum relative abundances ( $>15 \%)$ during MIS 5e, 5a, 3, and the Holocene (Alvarez Zarikian et al., 2009).

Genus Legitimocythere Coles and Whatley, 1989 (= Genus "Thalassocythere" Benson, 1977)

Legitimocythere acanthoderma (Brady) 1880, Pl. P1, figs. 4, 5 (Whatley and Coles, 1987).

Remarks: Legitimocythere acanthoderma was frequently found in relatively lower abundance $(<5 \%)$. Its occurrence appears to be associated with glacials and stadials (Alvarez Zarikian et al., 2009). This species is reported as "Thalassocythere" acanthoderma in Coles and Whatley, 1989 (Dingle and Lord, 1990).

\section{Genus Pennyella Neale, 1974 (= Genus "Oxycythereis"} Benson, 1974)

Pennyella dorsoserrata (Brady) 1880, Pl. P1, figs. 1, 2 (Whatley and Coles, 1987).

Pennyella horridus Whatley and Coles, 1987, Pl. P1, fig. 3 (Whatley and Coles, 1987).

Remarks: Genus Pennyella (as Oxycythereis in Whatley and Coles, 1987; Cronin et al., 1999; Didié and Bauch, 2000; and as Rugocythereis in Dingle and Lord, 1990) is represented by $P$. dorsoserrata and $P$. horridus. This genus was present in sediments deposited during MIS $5 \mathrm{a}, 5 \mathrm{c}$, 5e, and the Holocene and clearly showed its preference to interstadial and interglacial conditions (Alvarez Zarikian et al., 2009). It was also abundant in upper Pleistocene to Holocene sediments on the southern Rockall Plateau (Didié and Bauch, 2000).

Genus Pseudobosquetina Guernet and Moullade, 1994

Pseudobosquetina mucronalatum (Brady) 1880 (Whatley and Coles, 1987; Jellinek et al., 2006).

Pseudobosquetina nobilis Jellinek, Swanson, and Mazzini, 2006, Pl. P5, figs. 1, 2, 3 (Jellinek et al., 2006).

Remarks: Specimens of genus Pseudobosquetina found at Site U1314 were identified as P. mucronalatum in Alvarez Zarikian et al. (2009) (as Bosquetina mucronalatum in Whatley and Coles, 1987; Didié and Bauch, 2000, 2001; as Pterygocythere mucronalatum in Ayress et al., 2004), but further examination showed that some of the specimens may also belong to P. nobilis Jellinek, Swanson, and Mazzini, 2006. Pseudobosquetina showed highest abundances (>12\%) during MIS 5e and occurred sporadically at lower levels during 
MIS 5b-5d, 6, 4, 3, 2, and 1 (Alvarez Zarikian et al., 2009). Pseudobosquetina is a cosmopolitan abyssal genus commonly found in the Atlantic and Pacific oceans. It is considered to be an important component of ostracode assemblages found in sediments bathed by lower NADW and AABW for its modern bathymetric distribution (2400 to $>4600 \mathrm{~m}$ ) and association with deepwater masses (Dingle and Lord, 1990; Ayress et al., 1997; Yasuhara et al., 2008b). P. nobilis occurs in the North Atlantic and the southeast Atlantic (Jellinek et al., 2006).

\section{Family XESTOLEBERIDAE Sars, 1928 Genus Xestoleberis Sars, 1866}

Xestoleberis profundis Whatley and Coles, 1987, Pl. P7, fig. 6 (Whatley and Coles, 1987).

Remarks: Xestoleberis profundis peaked at the MIS 3-2 and MIS 6-5 transitions. It has been recovered from the central North Atlantic (Whatley and Coles, 1987; Van Harten, 1990) and South Atlantic (Yasuhara et al., 2008b) at depths ranging from 2600 to $5000 \mathrm{~m}$.

Suborder BAIRDIOCOPINA

Superfamily BAIRDIOIDEA Sars, 1887

Family BAIRDIIDAE Sars, 1887

Genus Bairdoppilata Coryell, Sample, and Jennings, 1935

Bairdoppilata victrix (Brady) 1954, Pl. P10, figs. 1, 2 (Whatley and Coles, 1987).

Remarks: Bairdoppilata victrix was found in core samples associated with glacial and stadial intervals. This species is found in deep waters in the North Atlantic (Whatley and Coles, 1987; Didié, 2001) and has been linked to glacial assemblages on the Rockall Plateau (Didié and Bauch, 2000).

Family BYTHOCYPRIDIDAE Maddocks, 1969 Genus Bythocypris Brady, 1880

(Pl. P10, figs. 4, 5, 6)

Remarks: Specimens of this genus were found sporadically throughout the core section in intervals typically associated with glacial stages. This is a widely distributed deep-sea ostracode.

\section{Suborder CYPRIDOCOPINA Jones, 1901 Superfamily MACROCYPRIDOIDEA Müller, 1912 \\ Family MACROCYPRIDIDAE Müller, 1912 \\ Genus Macrocypris Brady, 1868 \\ (Whatley and Coles, 1987)}

Remarks: Scattered findings in low numbers.

Superfamily PONTOCYPRIDOIDEA Müller, 1894

Family PONTOCYPRIDIDAE_-_Müller, 1894 Genus Argilloecia Sars, 1866

Argilloecia spp., Pl. P8, figs. 1-6 (Whatley and Coles, 1987).

Remarks: At least four different species of Argilloecia were recognized (three are illustrated in Pl. P8). Two corre- spond to Argilloecia sp. 5 and Argilloecia sp. 6 distinguished by Whatley and Coles (1987) in sediments cored at Deep Sea Drilling Project Leg 94 sites in the North Atlantic. Highest relative abundances of this genus are restricted to MIS 5e and 5c (up to $20 \%$ of the fauna), while it exhibits slightly lower abundances during Interstadial $5 a$, the early part of the MIS 3, and the Holocene. Intervals when Argilloecia displays maximum abundances are concurrent with intervals of maximum $\mathrm{CaCO}_{3}$ and minimum IRD content in the sediments (Alvarez Zarikian et al., 2009).

\section{Genus Propontocypris Sylvester-Bradley, 1947}

Propontocypris trigonella (Sars), Pl. P8, fig. 10 (Whatley and Coles, 1987).

Remarks: $P$. trigonella showed a similar downcore distribution as Argilloecia, but also peaked during an interval in MIS 6 centered at $\sim 145 \mathrm{ka}$. Most species of Propontocypris are quick swimmers, known to feed on decaying animal and plant tissue (Maddocks and Steineck, 1987), and some of them have been reported from deepwater vents associated with cold-sea biota (personal observation).

\section{Suborder PLATYCOPINA Sylvester-Bradley, 1961 Superfamily CYTHERELLOIDEA Sars, 1866 Family CYTHERELLIDAE Sars, 1866 Genus Cytherella Jones, 1849}

Remarks: Two specimens of Cytherella were found throughout the entire stratigraphic section studied. They belong to the same species illustrated in Didié and Bauch (2000, 2001) as Cytherella sp. 1 (Pl. P10, fig. 5).

\section{Acknowledgments}

This research used samples and/or data provided by the Integrated Ocean Drilling Program (IODP) collected during IODP Expedition 306. Funding for this research was provided Joint Oceanographic Institutions/US Science Support Program Grant Number JSA13 (T306A13). I am grateful to all Expedition 306 scientists, Anna Stepanova for assistance in ostracode identification and taxonomy, Katerina Petronotis for generating the North Atlantic bathymetric map illustration using GMT, and Tom Stephens and Mike Pendleton from the Microscopy and Imaging Center at Texas A\&M University for assistance. The FE-SEM acquisition of the center was supported by National Science Foundation Grant DBI-0116835, the Vice President for Research Office and the Texas Engineering Experiment Station.

\section{References}

Alvarez Zarikian, C.A., Stepanova, A.Y., and Grützner, J., 2009. Glacial-interglacial variability in deep sea ostracod assemblage composition at IODP Site U1314 in the 
subpolar North Atlantic. Mar. Geol., 258(1-4):69-87. doi:10.1016/j.margeo.2008.11.009

Athersuch, J., 1979. On Pelecocythere sylvester bradleyi Athersuch gen. et. sp. nov. Stereo-Atlas Ostracod Shells, 6(3):13-20.

Athersuch, J., Horne, D.J., and Whittaker, J.E., 1989. Marine and Brackish Water Ostracods: Avon (Bath Press).

Ayress, M., Neil, H., Passlow, V., and Swanson, K., 1997. Benthonic ostracods and deep watermasses: a qualitative comparison of southwest Pacific, Southern and Atlantic Oceans. Palaeogeogr., Palaeoclimatol., Palaeoecol., 131(3-4):287-302. doi:10.1016/S0031-0182(97)000072

Ayress, M.A., 1991. On Arcacythere Hornibrook, 1952 (Cytheracea, Crustacea), a senior synonym of Rockallia Whatley, Frame and Whittaker, 1978. J. Micropaleontol., 10(2): 223-226.

Ayress, M.A., DeDeckker, P., and Coles, G.P., 2004. A taxonomic and distributional survey of marine benthic Ostracoda off Kerguelen and Heard Islands, South Indian Ocean. J. Micropalaeontol., 23:15-38.

Benson, R., 1972. The Bradleya problem, with description of two new psychrospheric ostracode genera, Agrenocythere and Poseidonamicus (Ostracoda: Crustacea). Smithsonian Contrib. Paleobiol., 12:1-138.

Benson, R.H., DelGrosso, R.M., and Steineck, P.L., 1983. Ostrocode distribution and biofacies, Newfoundland continental slope and rise. Micropaleontology, 29(4):430453. doi:10.2307/1485518

Channell, J.E.T., Hodell, D.A., and Lehman, B., 1997. Relative geomagnetic paleointensity and $\delta^{18} \mathrm{O}$ at ODP Site 983 (Gardar Drift, North Atlantic) since $350 \mathrm{ka}$. Earth Planet. Sci. Lett., 153(1-2):103-118. doi:10.1016/ S0012-821X(97)00164-7

Channell, J.E.T., Hodell, D.A., McManus, J., and Lehman, B., 1998. Orbital modulation of the Earth's magnetic field intensity. Nature (London, U. K.), 394:464-468. doi:10.1038/28833

Coles, G., and Whatley, R., 1989. New Paleogene to Miocene genera and species of Ostracoda from DSDP Sites in the North Atlantic. Rev. Esp. Micropaleontol., 21:81124.

Coles, G.P., Whatley, R.C., and Moguilevsky, A., 1994. The ostracod genus Krithe from the Tertiary and Quarternary of the North Atlantic. Peontology, 37(1):71-120.

Corrège, T., 1993. The relationship between water masses and benthic ostracod assemblages in the western Coral Sea, Southwest Pacific. Palaeogeogr., Palaeoclimatol., Palaeoecol., 105(3-4):245-266. doi:10.1016/00310182(93)90086-X

Corrège, T., Ayress, M.A., and Drapala, V., 1992. On Swainocythere nanseni (Joy and Clark). Stereo-Atlas Ostracod Shells, 19(2):107-110.

Cronin, T.M. 1981. Paleoclimatic implications of late Pleistocene marine ostracodes from the St. Lawrence Lowlands. Micropaleontology, 27(4): 384-418. doi:10.2307/ 1485193

Cronin, T.M., 1983. Bathyal ostracodes from the FloridaHatteras slope, the straits of Florida, and the Blake Pla- teau. Mar. Micropaleontol., 8(2):89-119. doi:10.1016/ 0377-8398(83)90007-5

Cronin, T.M., 1991. Late Neogene marine Ostracoda from Tjørnes, Iceland. J. Paleontol., 65(5):767-794.

Cronin, T.M., Boomer, I., Dwyer, G.S., and Rodriguez-Lázaro, J., 2002. Ostracoda and paleoceanography. In Holmes, J.A., and Chivas, A.R. (Eds.), The Ostracoda: Applications in Quaternary Research: Washington, DC (Am. Geophys. Union), 99-119.

Cronin, T.M., DeMartino, D.M., Dwyer, G.S., and Rodriguez-Lazaro, J., 1999. Deep-sea ostracode species diversity: response to late Quaternary climate change. Mar. Micropaleontol., 37(3-4): 231-249. doi:10.1016/S03778398(99)00026-2

Cronin, T.M., Holtz, T.R., Jr., Stein, R., Spielhagen, R., Fütterer, D., and Wollenberg, J., 1995. Late Quaternary paleoceanography of the Eurasian Basin, Arctic Ocean. Paleoceanography, 10(2):259-281. doi:10.1029/ 94PA03149

Cronin, T.M., Holtz, T.R., Jr., and Whatley, R.C., 1994. Quaternary paleoceanography of the deep Arctic Ocean based on quantitative analysis of Ostracoda. Mar. Geol., 19(3-4):305-332. doi:10.1016/0025-3227(94)90188-0

Cronin, T.M., Raymo, M.E., and Kyle, K.P., 1996. Pliocene (3.2-2.4 Ma) ostracode faunal cycles and deep ocean circulation, North Atlantic Ocean. Geology, 24(8):695-698. doi:10.1130/00917613(1996)024<0695:PMOFCA >2.3.CO;2

Cronin, T.M., Whatley, R., Wood, A., Tsukagoshi, A., Ikeya, N., Brouwers, E.M., and Briggs, W.M., Jr., 1993. Microfaunal evidence for elevated Pliocene temperatures in the Arctic Ocean. Paleoceanography, 8(2):161-173. doi:10.1029/93PA00060

Dickson, R.R., and Brown, J., 1994. The production of North Atlantic Deep Water: sources, rates, and pathways J. Geophys. Res., [Oceans], 99(C6):12319-12341. doi:10.1029/94JC00530

Didié, C., 2001. Late Quaternary climate variations recorded in North Atlantic deep-sea benthic ostracodes. Ber. Polar Meeresforsch., 390:1-121.

Didié, C., and Bauch, H.A., 2000. Species composition and glacial-interglacial variations in the ostracode fauna of the northeast Atlantic during the past 200,000 years. Mar. Micropaleontol., 40(1-2):105-129. doi:10.1016/ S0377-8398(00)00034-7

Didié, C., and Bauch, H.A., 2001. Erratum to "Species composition and glacial-interglacial variations in the ostracode fauna of the northeast Atlantic during the past 200,000 years" [Marine Micropaleontology, 40 (2000) 105-129]. Mar. Micropaleontol., 40:105-129.

Didié, C., and Bauch, H.A., 2002. Implications of upper Quaternary stable isotope records of marine ostracodes and benthic foraminifers for paleoecological and paleoceanographical reconstructions. In Holmes, J.A., and Chivas, A.R. (Eds.), The Ostracoda: Applications in Quaternary Research: Washington, DC (Am. Geophys. Union), 279-299.

Didié, C., Bauch, H.A., and Helmke, J.P., 2002. Late Quaternary deep-sea ostracodes in the polar and subpolar North Atlantic: paleoecological and paleoenvironmen- 
tal implications. Palaeogeogr., Palaeoclimatol., Palaeoecol., 184(1-2):195-212. doi:10.1016/S0031-0182(02)002596

Dingle, R.V., and Lord, A.R., 1990. Benthic ostracods and deep water-masses in the Atlantic Ocean. Palaeogeogr., Palaeoecol., Palaeoecol., 80(3-4):213-235. doi:10.1016/ 0031-0182(90)90133-R

Dingle, R.V., Lord, A.R., and Boomer, I.D., 1989. Ostracod faunas and water masses across the continental margin off southwestern Africa. Mar. Geol., 87(2-4):323-328. doi:10.1016/0025-3227(89)90069-8

Flower, B.P., Oppo, D.W., McManus, J.F., Venz, K.A., Hodell, D.A., and Cullen, J.L., 2000. North Atlantic Intermediate to Deep Water circulation and chemical stratification during the past 1 Myr. Paleoceanography, 15(4):388-403. doi:10.1029/1999PA000430

Guernet, C., and Fourcade, E., 1988. Cenozoic ostracodes from Hole 628A, ODP Leg 101, Bahamas. In Austin, J.A., Jr., Schlager, W., et al., Proc. ODP, Sci. Results, 101: College Station, TX (Ocean Drilling Program), 139-151. doi:10.2973/odp.proc.sr.101.123.1988

Hao, Y.-C., 1988. Systematic description of microfossils, 2. Ostracoda. In Ruan, P.H., and Hao, Y.-C. (Eds.), Quaternary Microbiota in the Okinawa Trough and Their Geological Significance: Beijing (Geol. Publ. House), 227-395.

Jansen, E., Raymo, M.E., Blum, P., et al., 1996. Proc. ODP, Init. Repts., 162: College Station, TX (Ocean Drilling Program). doi:10.2973/odp.proc.ir.162.1996

Jellinek, T., Swanson, K., and Mazzini, I., 2006. Is the cosmopolitan model still valid for deep sea podocopid ostracods? (with the discussion of two new species of the genus Pseudobosquetina Guernet and Moullade 1994 and Cytheropteron testudo [Ostracoda] as case studies). Senckenbergiana marit., 36(1):29-50.

Jones, R.L., Whatley, R.C., and Cronin, T.M., 1998. The zoographical distribution of deep water Ostracoda in the Arctic Ocean. In Crasquin-Soleau, S., Braccini., E., and Lethiers, F. (Eds.), What about Ostracoda! Proc. 3rd Eur. Ostracodologists Meet., 83-90.

Joy, J.A., and Clark, D.L., 1977. The distribution, ecology and systematics of the benthic Ostracoda of the central Arctic Ocean. Micropaleontology, 23(2):129-154. doi:10.2307/1485329

Maddocks, R.F., and Steineck, P.L., 1987. Ostracoda from experimental wood-island habitats in the deep sea. Micropaleontology, 33(4): 318-355. doi:10.2307/ 1485572

McCave, I.N., and Tucholke, B.E., 1986. Deep current-controlled sedimentation in the western North Atlantic. In Vogt, P.R., and Tucholke, B.E. (Eds.), The Geology of North America: The Western North Atlantic Region (Volume M). Boulder, CO (Geol. Soc. Am.), 451-468.

Neale, J.W., and Howe, H.V., 1975. The marine Ostracoda of Russian Harbour Novaya Zemlya and other high latitude faunas. Bull. Am. Paleontol., 65:381-431.

Neale, J.W., 1988. The anatomy of the ostracod Pelecocythere purii sp. nov, and some features connected with the abyssal mode of life in this and some other deep water forms. In Hanai, T., Ikeya, N., and Ishizaki, K.
(Eds.), Evolutionary Biology of Ostracoda, its Fundamentals and Applications: Tokyo (Elsevier), 709-720.

Raymo, M.E., Ganley, K., Carter, S., Oppo, D.W., and McManus, J., 1998. Millenial-scale climate instability during the early Pleistocene epoch. Nature (London, $U$. K.), 392(6677):699-702. doi:10.1038/33658

Rodriguez-Lázaro, J., and Cronin, T.M., 1999. Quaternary glacial and deglacial Ostracoda in the thermocline of the Little Bahama Bank (NW Atlantic): palaeoceanographic implications. Palaeogeogr., Palaeoclimatol., Palaeoecol., 152(3-4):339-364. doi:10.1016/S00310182(99)00048-6

Stein, R., Kanamatsu, T., Alvarez-Zarikian, C., Higgins, S.M., Channell, J.E.T., Aboud, E., Ohno, M., Acton, G.D., Akimoto, K., Bailey, I., Bjørklund, K.R., Evans, H., Nielsen, S.H.H., Fang, N., Ferretti, P., Gruetzner, J., Guyodo, Y.J.B., Hagino, K., Harris, R., Hatakeda, K., Hefter, J., Judge, S.A., Kulhanek, D.K., Nanayama, F., Rashid, H., Sierro Sanchez, F.J., Voelker, A., and Zhai, Q., 2006. North Atlantic paleoceanography: the last five million years. Eos, Trans. Am. Geophys. Union, 87(13):129-133. doi:10.1029/2006EO130002

Stepanova, A., Taldenkova, E., and Bauch, H.A., 2004. Ostracod species of the genus Cytheropteron from the Pleistocene, Holocene and Recent sediments of the Laptev Sea (Arctic Siberia). Rev. Esp. Micropaleontol., 36(1):83-108.

Stepanova, A.Y., 2006. Late Pleistocene-Holocene and Recent Ostracoda of the Laptev Sea and their importance for paleoenvironmental reconstructions. Paleontol. J., 40(S2):91-204. doi:10.1134/ S0031030106080016

Swanson, K.M., and Ayress, M.A., 1999. Cytheropteron testudo and related species from the SW Pacific with analyses of their soft anatomies, relationships and distribution. Senckenbergiana Biol., 79(2):151-193.

Van Harten, D., 1990. Modern abyssal ostracod faunas of the eastern Mid-Atlantic Ridge area in the North Atlantic and a comparison with the Mediterranean. In Whatley, R., and Maybury, C. (Eds.), Ostracoda and Global Events: London (Chapham and Hall), 321-328.

Whatley, R., and Coles, G., 1987. The late Miocene to Quaternary Ostracoda of Leg 94, Deep Sea Drilling Project. Rev. Esp. Micropaleontol., 19:33-97.

Whatley, R., Eynon, M., and Moguilevsky, A., 1996. Recent Ostracoda of the Scoresby Sund fjord system, East Greenland. Rev. Esp. Micropaleontol., 28(2):5-23.

Whatley, R., Eynon, M., and Moguilevsky, A., 1998. The depth distribution of Ostracoda from the Greenland Sea. J. Micropalaeontol., 17:15-32.

Whatley, R., and Masson, D.G., 1979. The ostracod genus Cytheropteron from the Quaternary and Recent of Great Britain. Rev. Esp. Micropaleontol., 11(2):223-277.

Whatley, R., Uffenorde, H., Harlow, C., Downing, S., and Kesler, K., 1982. The Rockalliidae, a new family of Cainozoic Cytheracean Ostracoda. J. Micropaleontol., 1:1-11.

Yasuhara, M., Cronin, T.M., deMenocal, P.B., Okahashi, H., and Linsley, B.K., 2008a. Abrupt climate change and collapse of deep-sea ecosystems. Proc. Natl. Acad. Sci. U. S. A., 105(5):1556-1560. doi:10.1073/pnas.0705486105 
Yasuhara, M., Cronin, T.M., and Matínez Arbizu, P., 2008b. Abyssal ostracods from the South and equatorial Atlantic Ocean: biological and paleoceanographic implications. DeepSea Res., Part I, 55(4): 490-497. doi:10.1016/j.dsr.2008.01.004
Initial receipt: 8 January 2009

Acceptance: 20 May 2009

Publication: 21 July 2009

MS 303306-213 
Figure F1. General bathymetric map of subpolar North Atlantic Ocean indicating IODP Site U1314 $\left(56^{\circ} 21.9^{\prime} \mathrm{N}\right.$, $27^{\circ} 53.3^{\prime} \mathrm{W}, 2820 \mathrm{~m}$ water depth) in the southern Gardar drift and Sites U1312 and U1313 also drilled during Expedition 306 (2 March-25 April 2005).

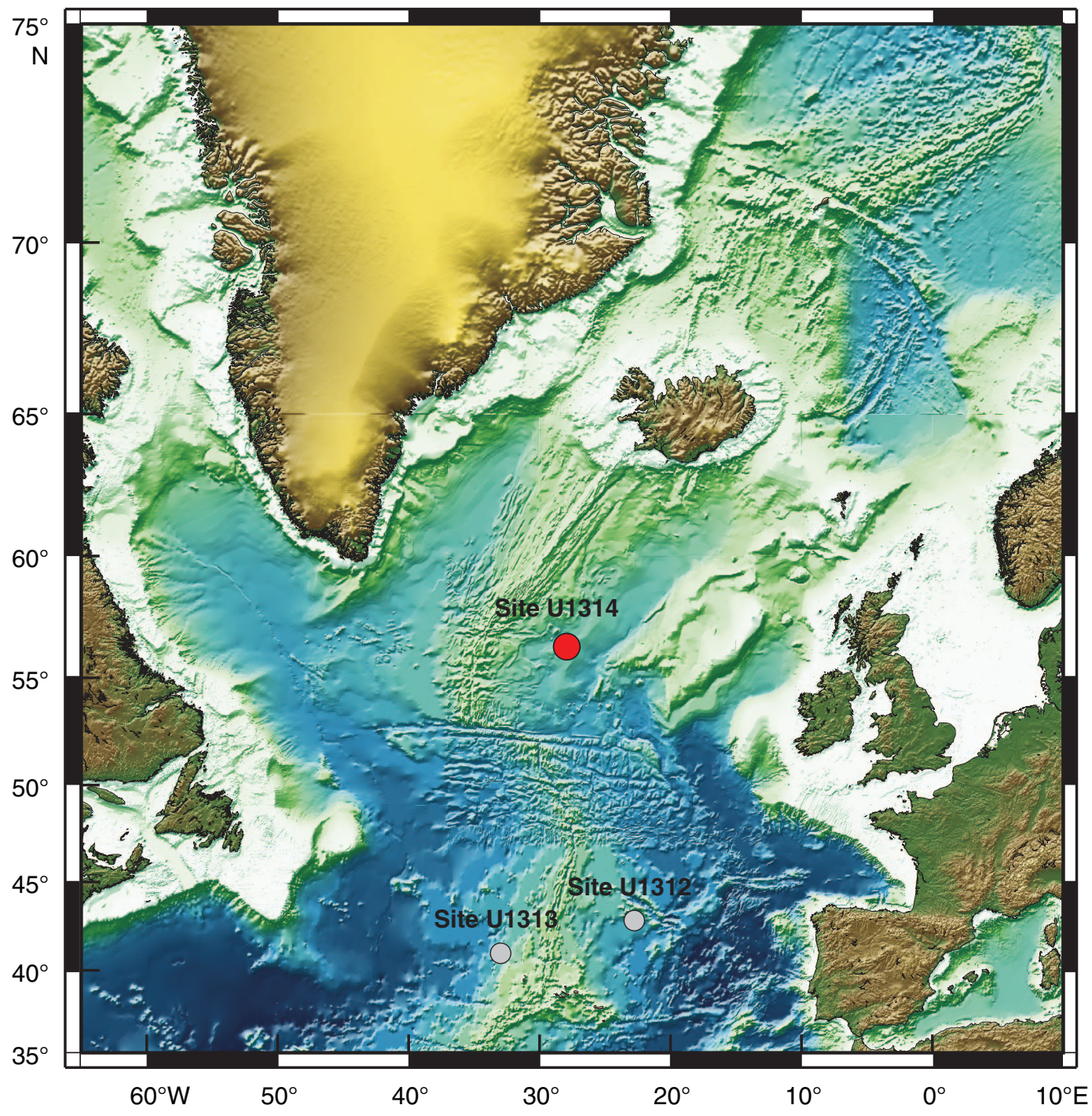


Table T1. Recognized ostracode taxa, Site U1314. This table is available in an oversized format. 
Plate P1. 1, 2. Pennyella dorsoserrata (Brady). 3. Pennyella horridus Whatley and Coles. 4, 6. Legitimocythere acanthoderma (Brady). Ostracode in 6 is juvenile. 5. Polycope cf. P. clathrata Sars. 7. Polycope orbicularis Sars. White scale bars $=200 \mu \mathrm{m}$.

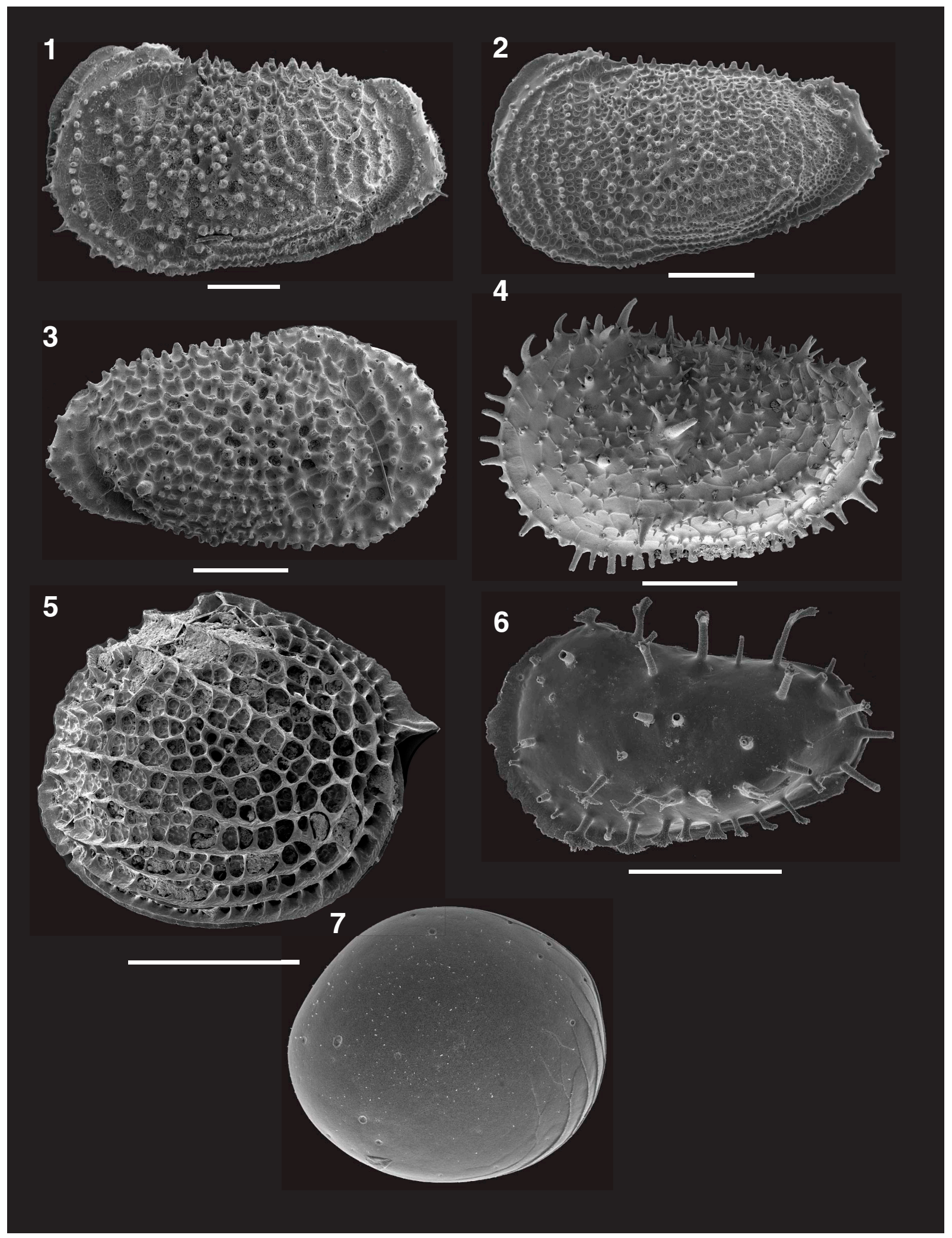


Plate P2. 1. Nannocythere sp. 2. Heinia dryppa Whatley and Coles. 3. Bythocythere bathytatos Whatley and Coles. 4. Pseudocythere caudata Sars. 5, 6. Pseudocythere sp. 2 sensu Didié and Bauch $(2000,2001)$. 7. Swainocythere nanseni (Joy and Clark). 8. Swainocythere sp. White scale bars $=200 \mu \mathrm{m}$.

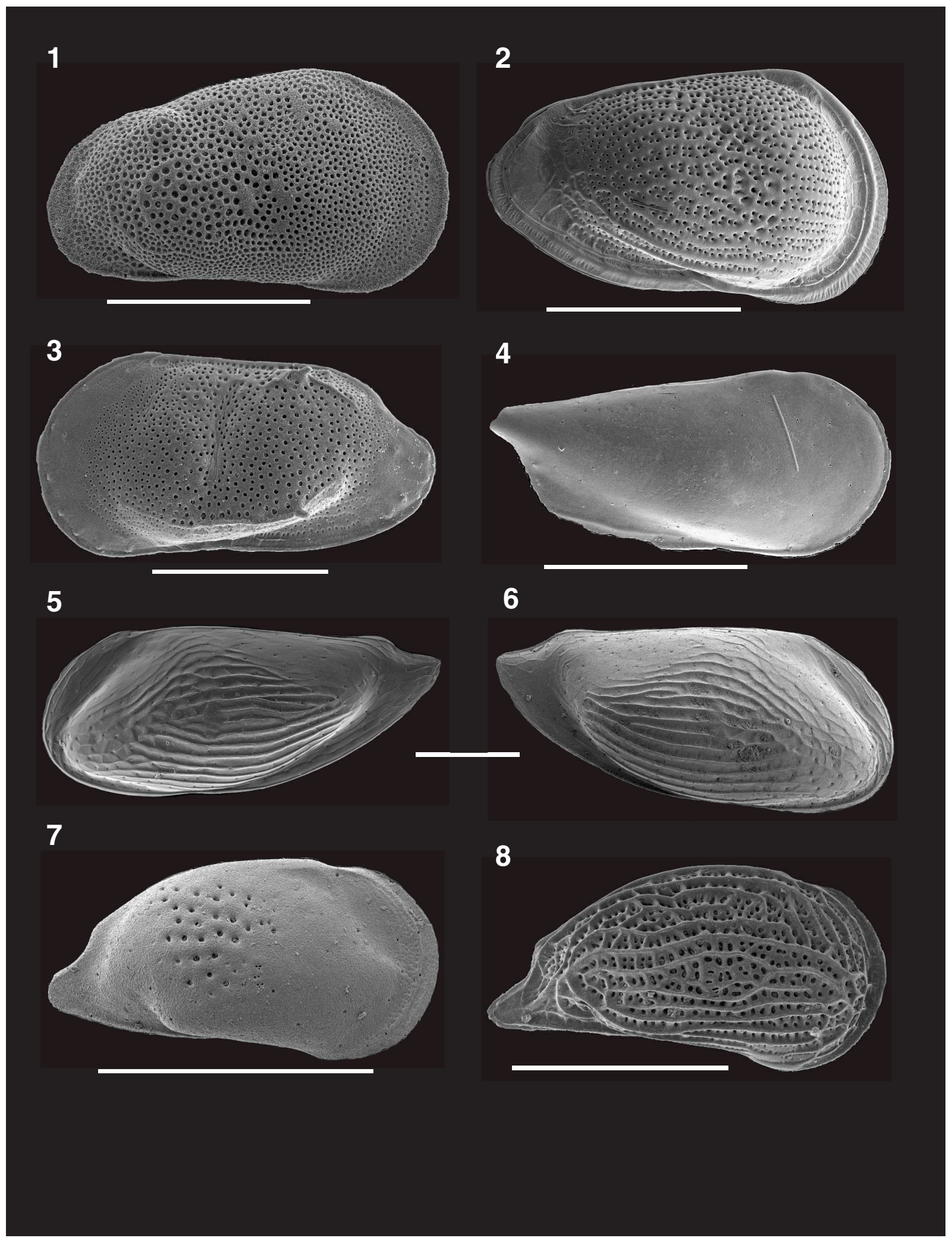


Plate P3. 1, 2. Cytheropteron perlaria Hao. 3, 5. Cytheropteron lineoporosa Whatley and Coles. 4. Cytheropteron alatum Sars. 6. Cytheropteron syntomalatum Whatley and Coles. 7. Aversovalva hydrodynamica Whatley and Coles. 8. Rimacytheropteron longipunctata (Breman). White scale bars $=200 \mu \mathrm{m}$.

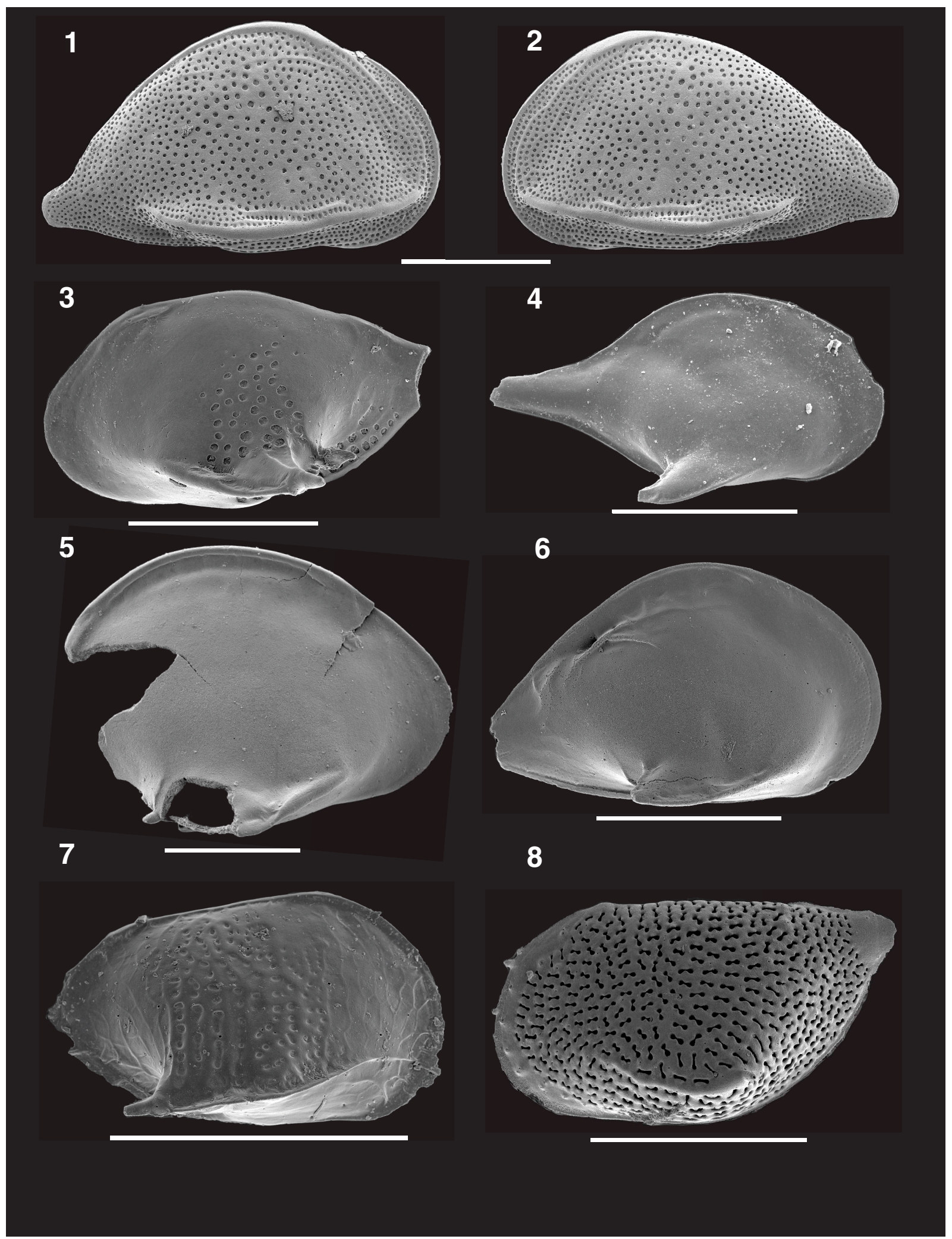


Plate P4. 1, 2. Cytheropteron tenuialatum Whatley and Coles. 3, 4. Cytheropteron circummuralla Whatley and Coles. 5, 6. Cytheropteron porterae Whatley and Coles. 7. Cytheropteron carolinae Whatley and Coles. 8. Cytheropteron arcuatum Brady, Crosskey and Robertson. White scale bars $=200 \mu \mathrm{m}$.

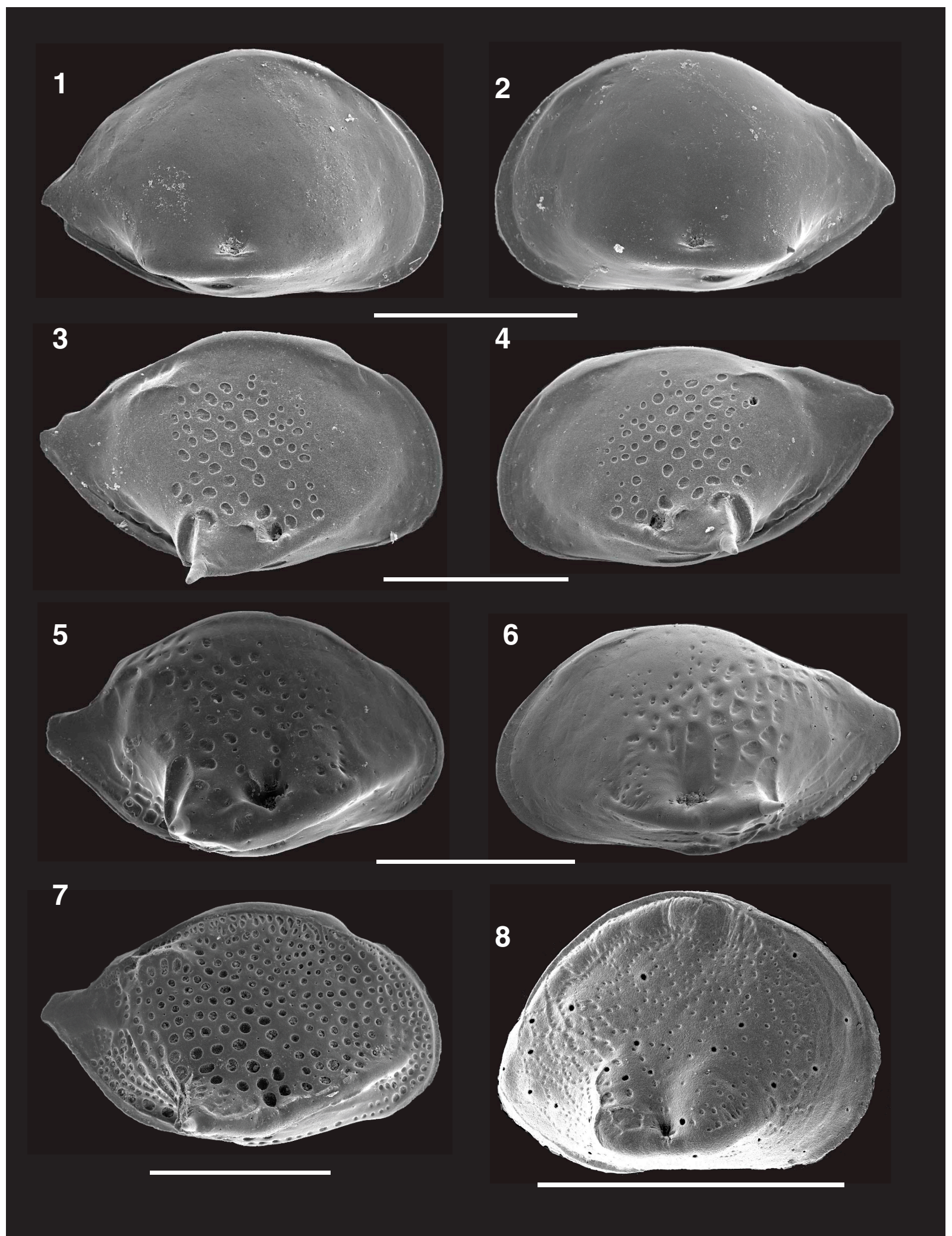


Plate P5. 1, 2, 3. Pseudobosquetina nobilis Jellinek, Swanson, and Mazzini. Ostracode in 3 is juvenile. 4. Pelecocythere sylvesterbradleyi Athersuch. 5. Bathycythere audax (Brady and Norman). 6, 7. Dutoitella suhmi (Brady). 8, 9. Bradleya dictyon (Brady). White scale bars $=200 \mu \mathrm{m}$.

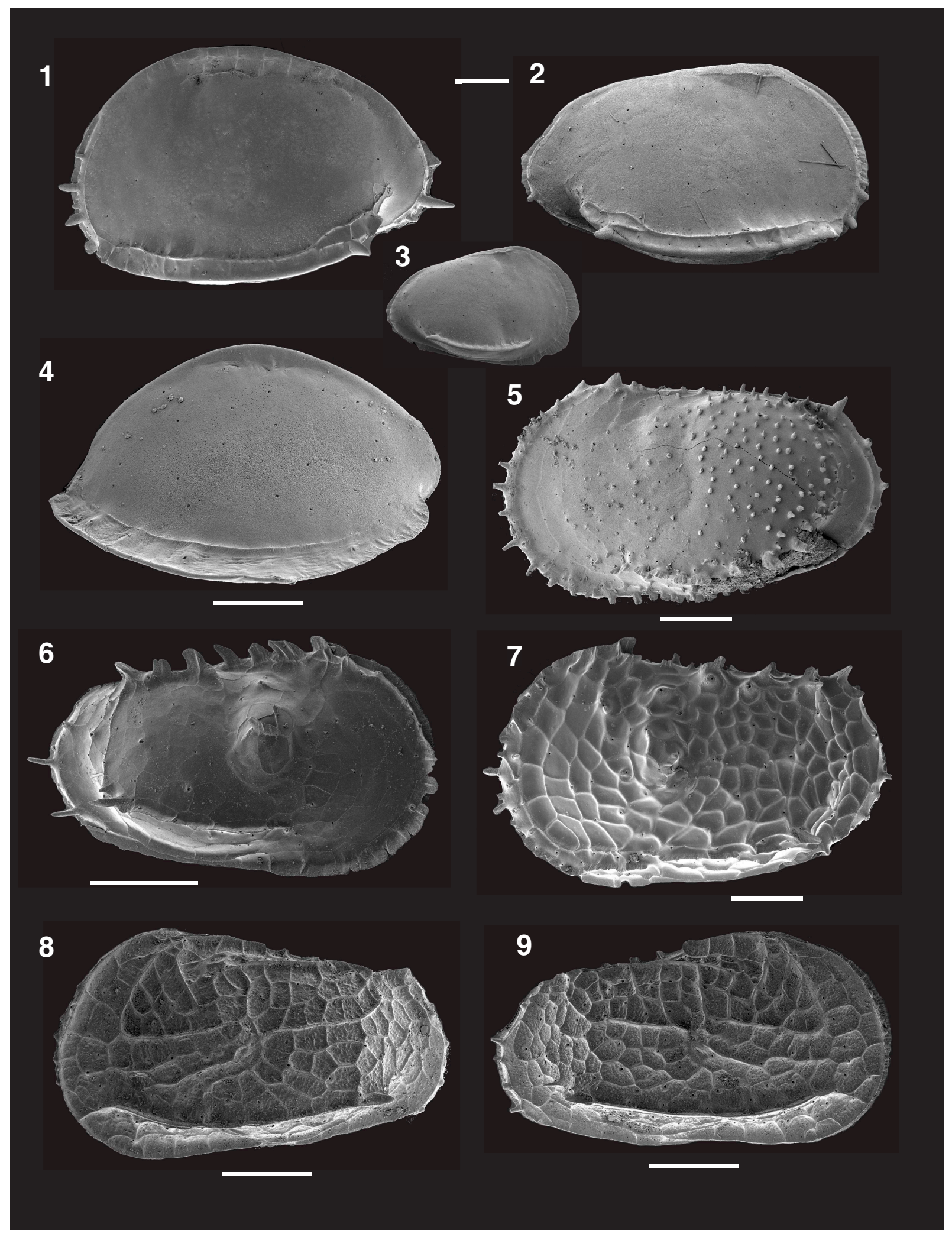


Plate P6. 1. Eucythere multipunctata Whatley and Coles. 2. Eucythere circumcostata Whatley and Coles. 3. Eucythere pubera Bonaduce, Ciampo, and Masoli. 4. Eucythere triangula Whatley and Coles. 5. Eucythere sp. 6, 7. Finmarchinella finmarchica (Sars). 8. Hemicythere villosa (Sars). White scale bars $=200 \mu \mathrm{m}$.

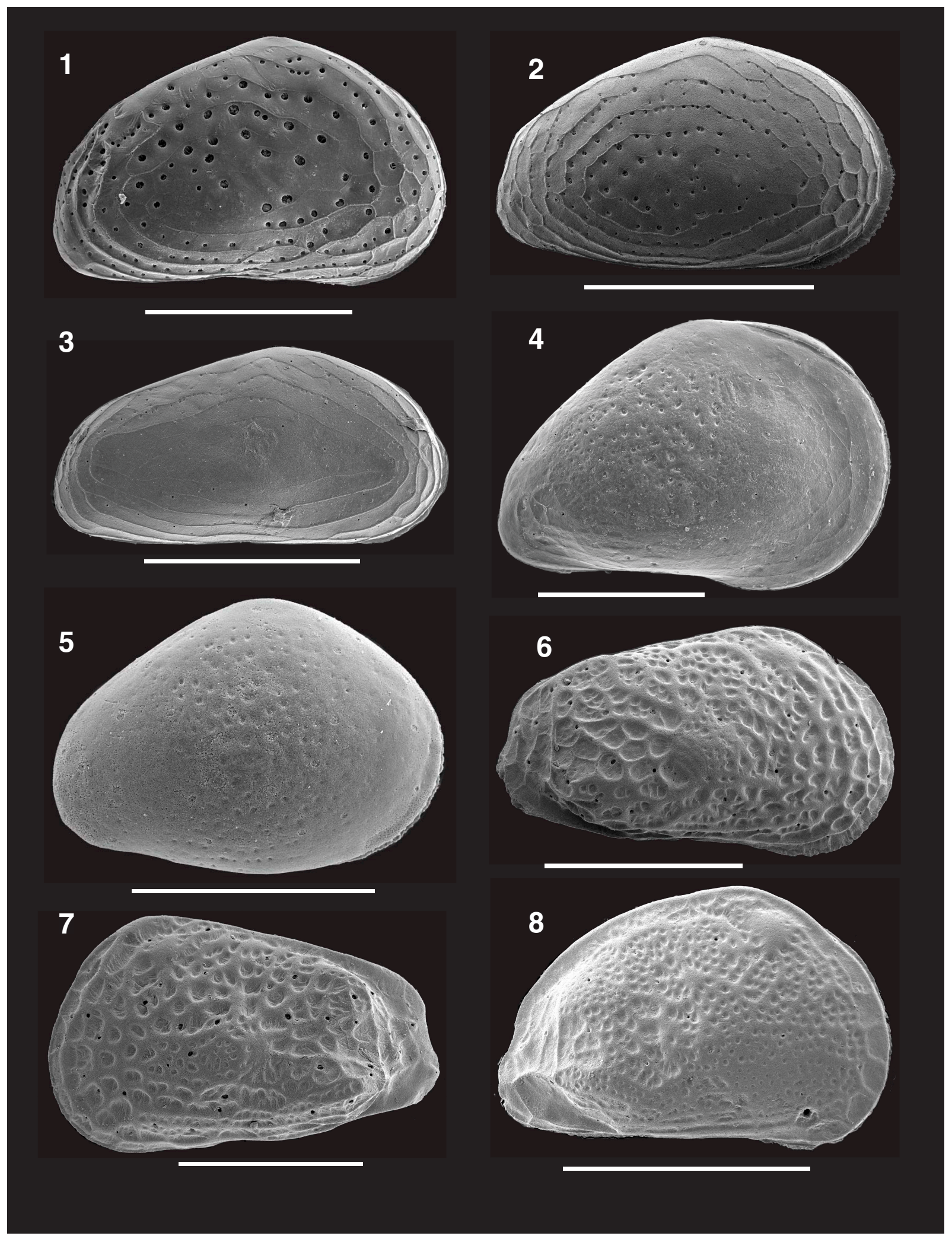


Plate P7. 1. Krithe morkhoveni van den Bold. 2. Krithe cf. K. aequabilis Campo. 3, 4. Krithe cf. K. dolichodeira van den Bold. 5. Krithe trinidadensis van den Bold. 6. Xestoleberis profundis Whatley and Coles. 7, 8. Loxoconchiid. White scale bars $=200 \mu \mathrm{m}$.

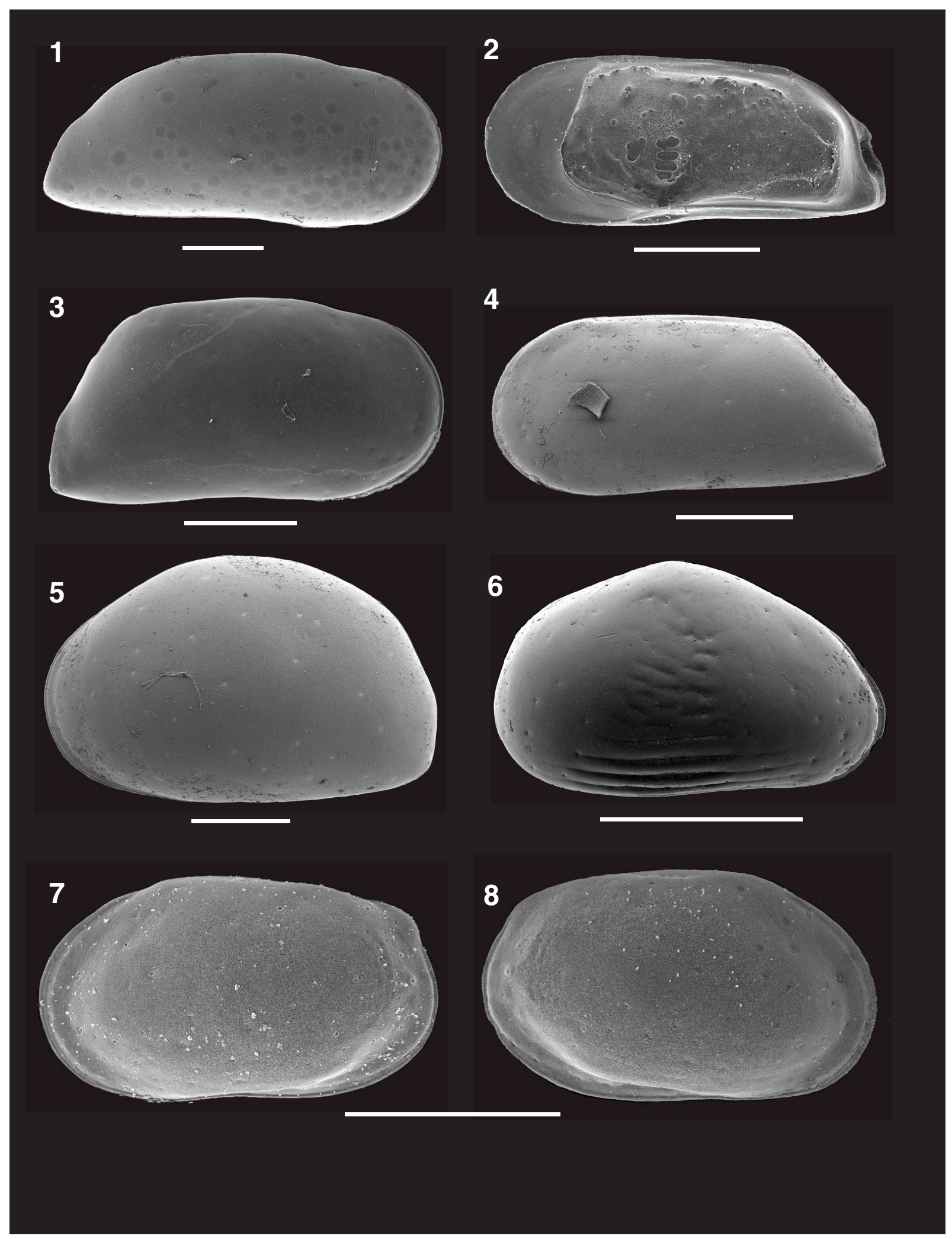


Plate P8. 1, 2. Argilloecia sp. 1 (Argilloecia sp. 5 of Whatley and Coles [1987]). 3, 4. Argilloecia sp. 2 (Argilloecia sp. 6 of Whatley and Coles [1987]). 5. Macrocypris sp. 6. Argilloecia sp. 3. 7, 8. Microcythere medistriatum (Joy and Clark). 9. Paracytherois flexuosa (Brady). 10. Propontocypris trigonella Sars. White scale bars $=200 \mu \mathrm{m}$.
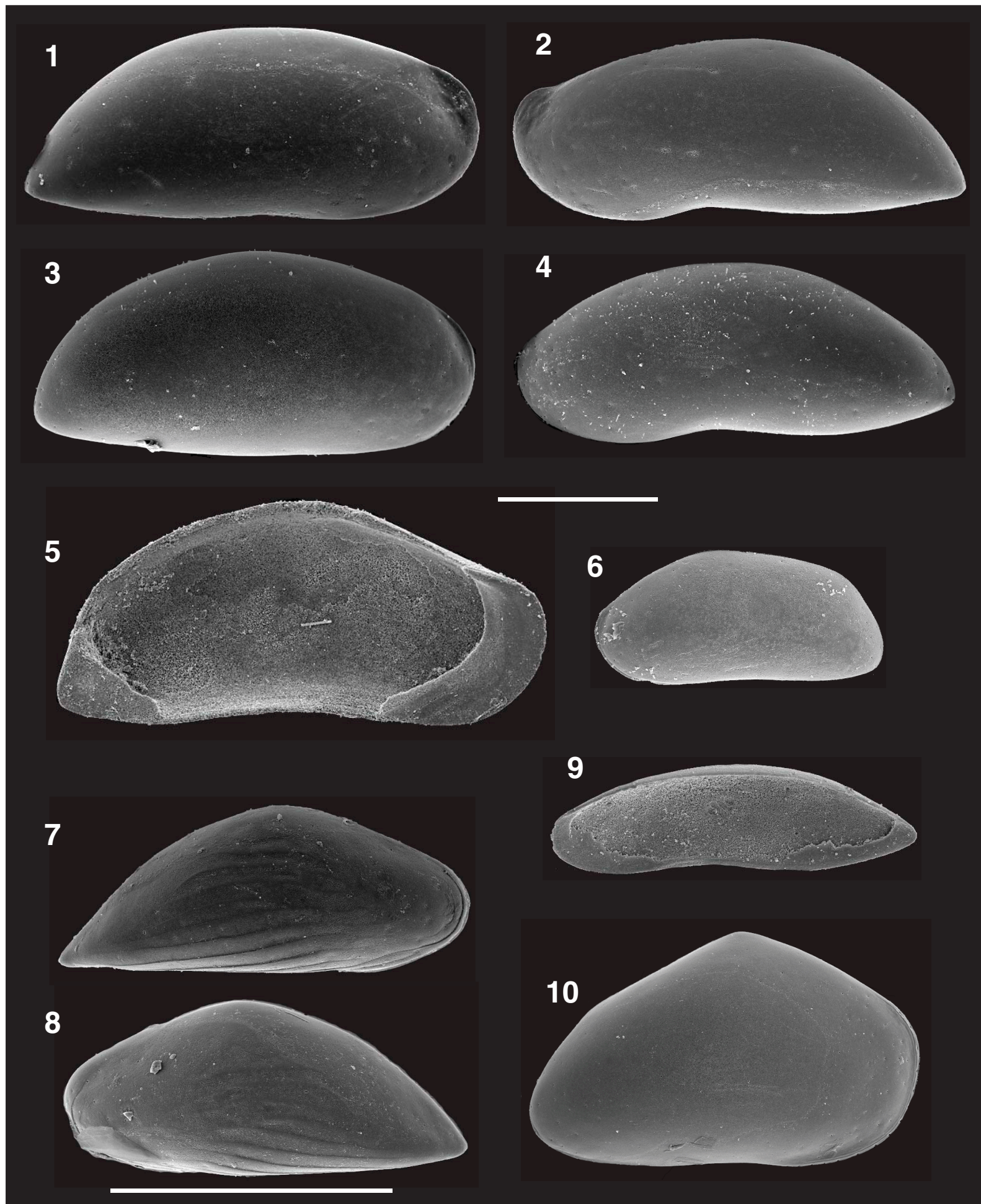
Plate P9. 1. Bradleya sp. (juvenile). 2. Bradleya normani Brady. 3, 4. Echinocythereis echinata (Sars). 5. Rockallia enigmatica Whatley, Frame, and Whittaker. 6, 7, 8. Henryhowella dasyderma (Brady). White scale bars $=200 \mu \mathrm{m}$.

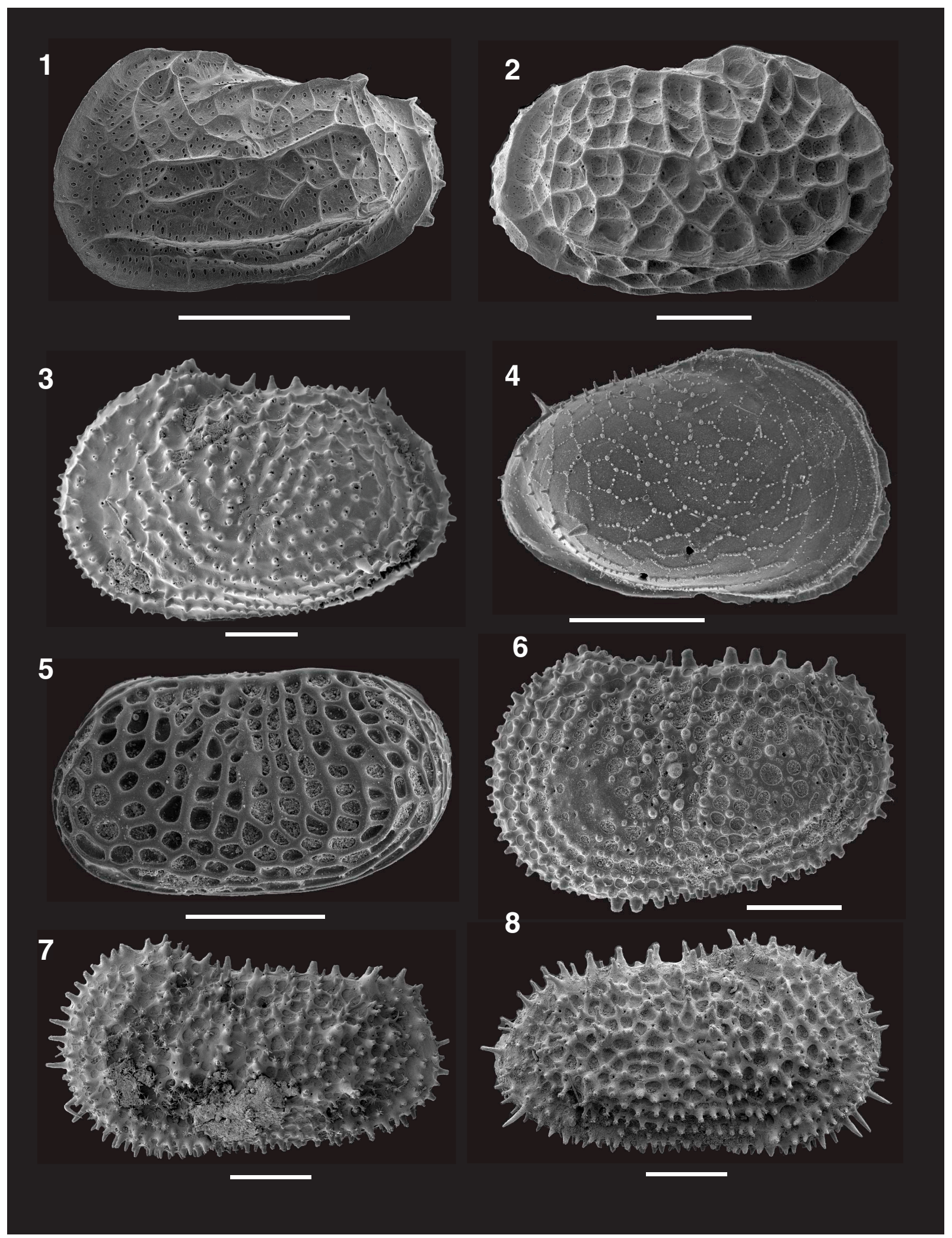


Plate P10. 1, 2. Bairdoppilata victrix (Brady). 3. Undetermined. 4, 6. Bythocypris sp. 5. Cytherella sp. 7. Ambocythere ramosa van den Bold. 8. Undetermined. White scale bars $=200 \mu \mathrm{m}$.

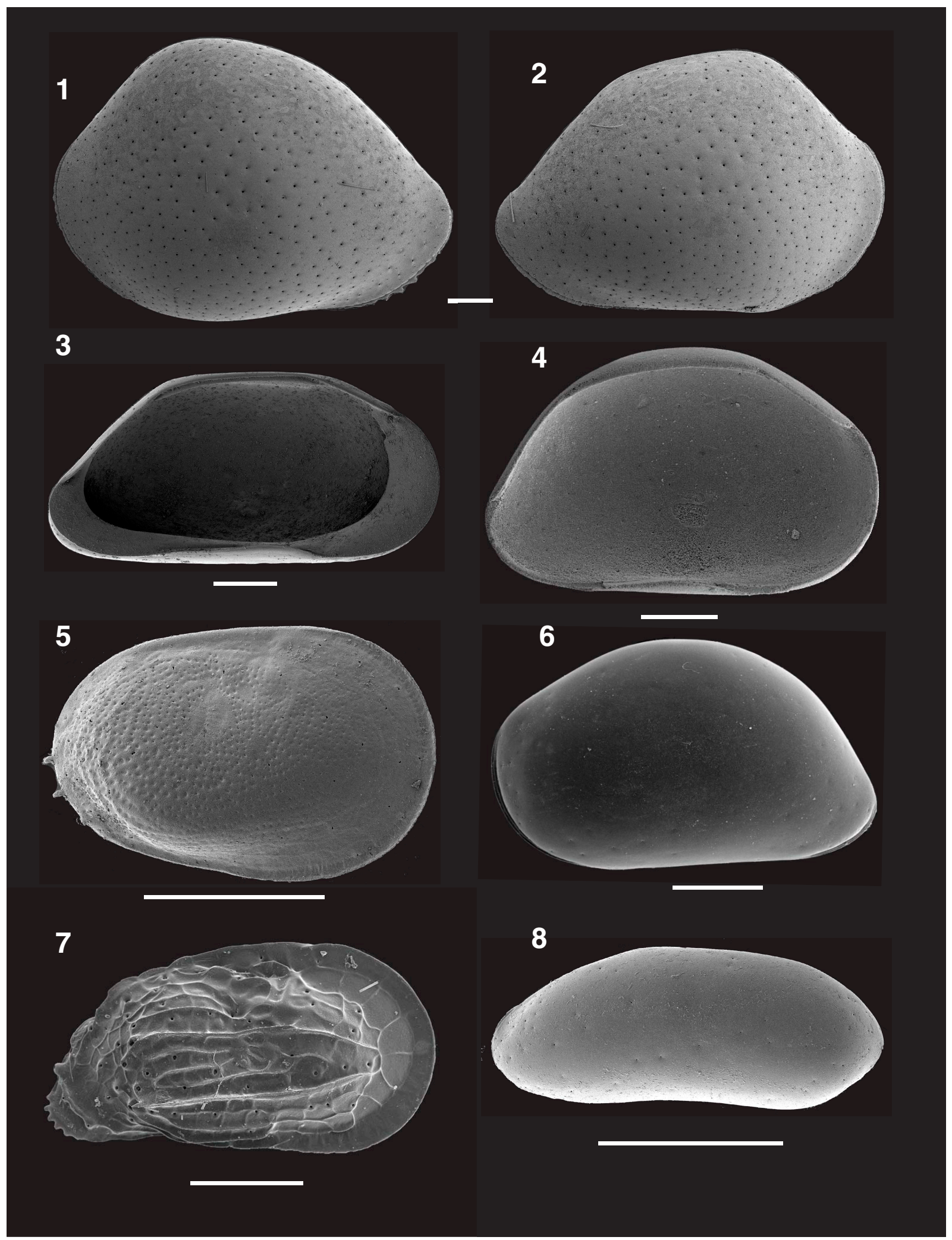

